\title{
Investment in Container Ships for the Yangtze River: A System Dynamics Model
}

\author{
Yan Jin \\ School of transportation, Wuhan University of Technology, Wuhan, Hubei, 430063,
}

China

\section{Introduction}

The Yangtze River, especially the Three-Gorge Reservoir, is becoming an important container transport route in the region of western China and some new container terminals have been built or are being planned or under construction (Fig.1). As the volume of the container goods grows, the trading of container ships in the area is likely to increase considerably.

But the special hydrographical condition raises a number of questions concerning the quality and operational suitability of existing container ships at present. Seasonal varying depth and water speed at different voyage passages in the Yangtze River and Three-Gorge Reservoir disturb the container ship sailing. As a consequence, traditional types of container ships serve without economic benefit. But the booming transport demand of containerized goods on the Yangtze River, especially in upstream and middle part, needs suitable and profitable container ships urgently. So the most important task is to invest in capacity of container ships to cope with the growing demand.

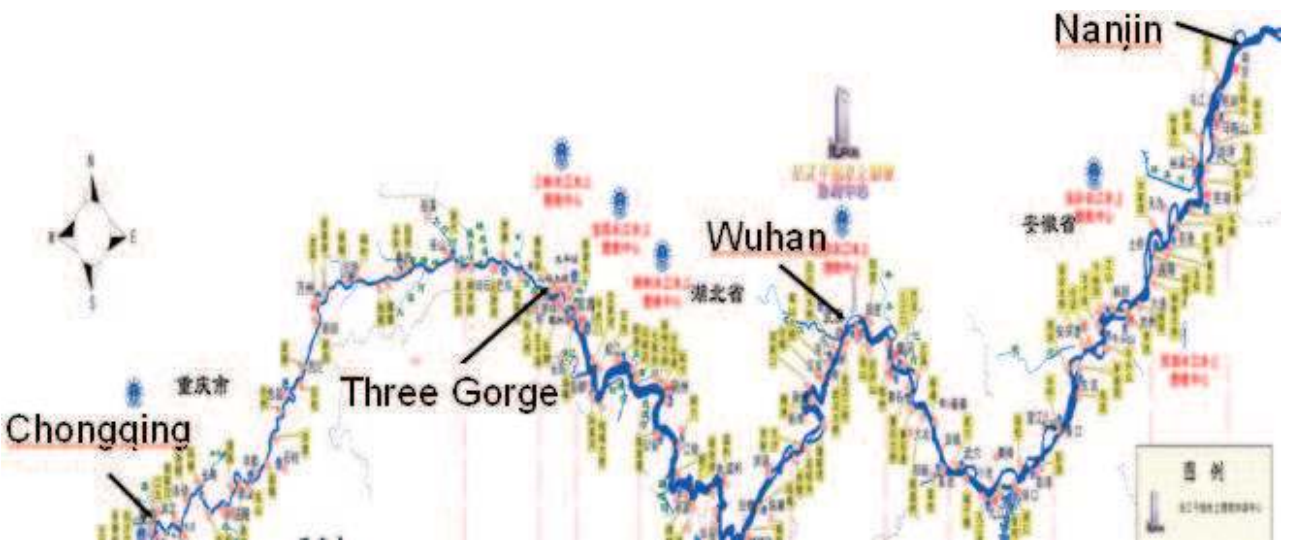

Fig. 1. Location of the main terminals in the Yangtze River

(Source: Jiangsu Marine Safety Administration)

Shipping is a capital-intensive industry with a history of sudden freight market booms and collapses. Estimating future transport demand and the ensuing adjustment of container ship

Source: Dynamic Modelling, Book edited by: Alisson V. Brito,

ISBN 978-953-7619-68-8, pp. 290, January 2010, INTECH, Croatia, downloaded from SCIYO.COM 
supply has proved to be extremely difficult (Tvedt, 2003). Depending on the available shipyard capacity, shipbuilding is a long process, taking usually two to three years. So investment decisions are made while freight rates and market demand are sprouting, but new capacity enters the market with a substantial time lag, possibly when both demand and prices are weak (Stopford, 2002). The fact that container ships tend to be expensive and nobody can make investment decisions easily, especially for ship owners who are willing to take their share of the growing container market in Yangtze River. A system dynamics method will be introduced in this paper to simulate the pattern of the container ships growing after making investment decision.

This paper is structured as follows. In the following two sections, system dynamics approach in shipping market is introduced through literature review and general introduction of the system dynamics theory. Then the complicated condition of the Yangtze River and the Three-Gorge Reservoir is presented in detail. In the system-dynamics simulation section, existing date on the container terminal capacity, number of vessel fleet and delay in new building of container ships are used to analyze the development of new types of container ships. In the last part the simulation results are analyzed which suggest that the change of river depth will affect the timing and duration of the development.

\section{Shipping market}

In general, the mechanism behind market cycles is very simple. According to Stopford (2000, pp.44), a shipping market cycle is a coordinator between supply and demand. The supply and demand model of economics is often used as a tool for analyzing market cycles. Most of the maritime economists accept that the shipping market is driven by a competitive process in which demand and supply determine the freight rate. On the demand side, the most important factor behind a shipping cycle is the business cycle of the world economy. Booming world economy increases the demand for transportation and, when the economy goes into recession, the world trade usually drops and the goods transportation eventually is reduced. Another class of factors influencing demand is sudden economic shocks like the oil crisis and wars. These events are unpredictable by nature, but still very important (Stopford, 2002).

The main cause of cyclicality in the supply side is the new shipbuilding cycle. Depending on the state of the shipbuilding market, the time lag between ordering a vessel and the delivery of it may range from one up to 3 or even 4 years. In the extreme shipyard market conditions of the 1970s, delivery times of 4-5 years were common (Stopford, 2002). Zannetos (1966) and Serghiou (1982) argue that ship-owners commonly overestimate economic opportunities when freight rates are rising, and order too many ships with a lag of about 6 months from the freight rate peak. That long delivery time implies that an unexpected upward jump in demand may leave freight rates high for some time until yards are able to deliver a sufficiently large number of new vessels. So the rate of investment in new tonnage is in most shipping markets volatile (Tvedt, 2003).

There has been a growing literature on asset valuation in the maritime industry that, inspired by the general finance literature, use continuous time price processes as a basis for deriving valuation models now (Tvedt, 2003). The earliest attempts at modeling were made by Tinbergen (1932), Koopmans (1939), Eriksen and Norman (1976), Charemza and Gronicki (1981), and Strandenes and Wergeland (2002). After Lucas's (1976) critique, rational expectations models that derive aggregate macroeconomic equations from the micro 
behavior of rational agents have become the standard. Also influential in the field, Beenstock and Vergottis (1993) employed the modern developments in dynamic macroeconomics and econometric theory to develop their econometric model of world shipping. Besides the inability of most structural models to outperform statistical models, economists have been suspicious of "black-box" type methodologies that do not take into account the ability of agents to learn rationally and adapt their optimal policies dynamically (Dikos, 2005).

The use of system dynamic models has not been common practice in the field of maritime economics, and especially in problems related to container shipping. The reasons for avoiding this approach may only be guessed, but, as Veenstra and Ludema (2003) argue, there are other commonly established research approaches, mostly based on econometric methods. In the beginning of the 1970s, Coyle (1977) conducted a study using system dynamics in order to analyze the design of an integrated oil supply system. The study was carried out for a major oil company, which already had effective processes for managing shipping operations. Dikos et al (2006) design a system-dynamics model for Niver Lines. The study was based on the situation prevailing in the oil industry at that time, which most of the oil company's required tanker capacity was controlled either by direct ownership or long time-charter contracts, while spot charters were only used to fill the gaps in seasonal demand. In all the models demand is decided by the world economy which is the big system.

This paper tempts to research the ship industry from a new point of the development of the terminal. As we know, the expansion of a terminal's capacity should be suitable for the growing of the goods, which means that we can use the expansion of the terminal's capacity to substitute the exogenous demand's change roughly. The substitution is reasonable when making research in the container transportation in the Yangtze, for the transportation is booming from now on.

\section{System-dynamics approach}

A system is a number of components integrated into a complex entity, and system analysis simply means the consideration of the entity rather than the separate consideration of individual components. The systems approach can be defined as an organized, efficient procedure for representing, analyzing and planning complex systems. It is a comprehensive, problem-solving methodology that involves two main steps: the rational and creative structuring of both quantitative and qualitative knowledge, mainly in the form of models, to represent problems; and the development of analytical techniques through which the problem can be analyzed and solved. System dynamics, a member of the family of systems approaches, provides a systematic framework for modeling and understanding a number of transport issues (Khaled et al, 1994).

In theory, the system-dynamics approach is a structural system with an architecture that incorporates cause and causality relations and provides a user-friendly interface for conducting sensitivity analyses. Furthermore, it does not require external calculations and allows users to incorporate their assessments on several external variables and fundamental relationships. Finally, it provides a framework for including feedback loops and nonlinear effects (Dikos et al, 2006).

From a manager's point of view, we tried to design a model that would contribute to the implementation of managerial practices in reality. System-dynamics modeling has the 
advantage of allowing the users to model the direct impact of changes in the market and dealing with the nonlinear problem with the feedback loops easily. System-dynamics problems suggest how the environment can act upon the system and contain feedback loops. In feedback situations, $X$ affects $Y$, and $Y$ in turn affects $X$, perhaps through a chain of causes and effects. One can not study the link between $X$ and $Y$ and, independently, the link between $Y$ and $X$ and predict how the system will behave. Only the study of the whole system as a feedback system will lead to correct results. Feedbacks are of two kinds (Sterman, 2000):

1. Self-reinforcing or positive feedback (Fig.2(a)), such as stock-market bubbles, compound interest, or breeding rabbits, accelerates growth or accelerates to a collapse.

2. Goal-seeking or negative feedback (Fig.2(b)), in which discrepancy induces corrective action to return the system to a target state or a long-term equilibrium.

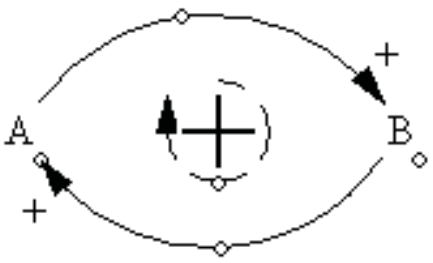

(a)

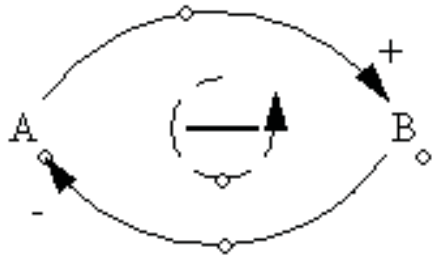

(b)

Fig. 2. (a) positive feedback (b) negative feedback

System-dynamics methods improve our understanding of the relationship between cause and effect and of the counterintuitive effects of delays and feedbacks. An industrial system is a complex multiple-loop interconnected system (basic loop as Fig.3) (Forrester, 1992). Decisions are made at multiple points throughout a system. Each resulting action generates information that may be used at several but not at all decision points. Feedback loops form the central structures that control change in all systems (Richardson, 1991). Likewise, feedback loops are the organizing structure around which system dynamics models are constructed.

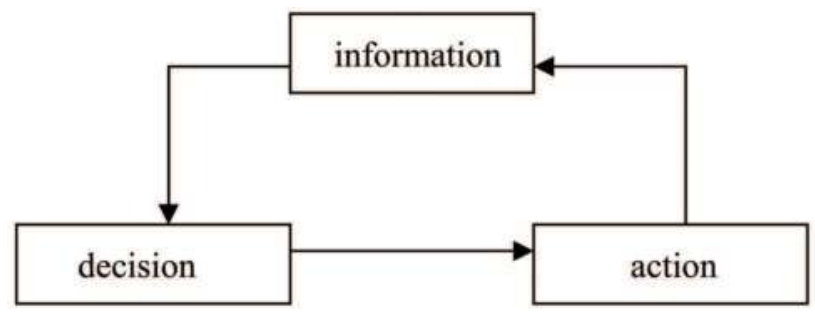

Fig. 3. Basic decision and information feedback (Source: Forrester, 1992)

System dynamics provide a qualitative and quantitative environment for modeling complex decision-making environments. I try to use system dynamics depending on my ability to design a changeable-draft container shipment from Chongqing Terminal with some loops, feedbacks, and decisions for analyzing the shipping investment. 


\section{Containerized transport market of the Yangtze}

\subsection{The development of containerized transport market of the Yangtze}

In the eighties of the 20th century, 17 domestic-trade container courses opened in China concentrated on the coastal course and range of the Yangtze-Jiangsu Province Section course mainly. The transported amount of containers by the waterway and port throughput increases progressively at the average speed of 5\% every year. From the Transportation Annual Bulletin in China 2004, the waterway container port throughput of our country finished 9.5 ten thousand TEU in 1985, the goods weighed 26 ten thousand tons, among them there are only 5.5 ten thousand TEU in the water way carrier of the Yangtze. In 1990, the waterway container port throughput of our country finished 7.3 ten thousand TEU, the goods weighed 20 ten thousand tons, among them the waterway delivery container traffic volume of the Yangtze accounts for 4.8 ten thousand TEU. By 1995, with the high-speed development of national economy, the domestic coastal container market increases fast, having driven the development of waterway containerized transport of the Yangtze too, the waterway container port throughput of the Yangtze River finishes 16 ten thousand TEU, the goods weigh 51 ten thousand tons. Since entering 21st century, as fast development of the regional economy of the Yangtze River Delta and our country implement the develop-thewest strategy, the waterway containerized transport of the Yangtze River has entered fast developing period. In 2003, the whole throughput of port container in the Yangtze River has already been up to 140 ten thousand TEU (Table 1).

\begin{tabular}{|c|c|c|c|c|}
\hline year & 1985 & 1990 & 1995 & 2003 \\
\hline $\begin{array}{c}\text { Inboard-trade containers by } \\
\text { Water in China }\end{array}$ & 9.5 & 7.3 & 20 & 400 \\
\hline Containers by the Yangtze & 5.5 & 4.8 & 16 & 140 \\
\hline
\end{tabular}

Source: http://www.chineseshipping.com.cn/statdata

Table 1. Containers transported in the Yangtze(ten thousands TEU)

From 1985 to 1990, the container demand was very low and most of them were abroad. At that time, terminals along the Yangtze were not suitable for handling containerized goods and no larger container vessels in the Yangtze can be chosen. If there were the inland containerized goods, the goods owners had to use the barges and pushers to transport them to Shanghai, which would take a lot of time. So most of owners preferred to transporting their goods to Hong Kong or Guangzhou by train and by this way the traffic cost was lower than to Shanghai. After 1995, the economy in Shanghai and Yangtze River Delta developed quickly. The government gave a great support for the construction of the Shanghai terminal and more and more foreign ship lines opened container courses. Then the container transportation in China increase quickly.

Container transportation in upstream part of the Yangtze River is a new focus in inland transportation of China, and China plans to boost shipping along the Yangtze River as a way to develop its western hinterland. On April 12, in Shanghai, the Yangtze Business Network 2007 is the first such event to lure investors to develop terminals long the so-called "Golden Waterway", which stretches 6,300 kilometers through seven provinces and the municipalities of Shanghai and Chongqing. So the container terminal of Chongqing plays an 
important role in the development of container transportation of the Yangtze River. According to the report of Shipping trade community 2004, Chongqing terminal has finished 92 thousand TEU in 2003, and it is estimated that its capacity will reach 700 thousand TEU in 2010 (Liu, 2005).

\subsection{The hydrographical condition of the Yangtze}

With the development of the economy in the middle and western part of China, more and more goods must be transported to the eastern China and to abroad from Chongqing terminal. But the original natural environment of the River, especially upstream part with a lot of riffles and low depth of water, is not suitable for bigger vessels to sail. According to the newly hydrographical investigation of the Yangtze River by CCS in 2004, the depth along the upstream part is different at different voyage passage because after the construction of Three-Gorge Dam, the water reserved in the reservoir can affect the depth and speed of the whole upstream part water remarkably. In general, we can divide the whole river into four ranges named natural part above dam, reservoir, between dams (Three-Gorge Dam and Ge-Zhou Dam), and natural part below dam. Meanwhile, the whole serving year can be divided into three periods named low, middle and high because the season will also affect the hydrographical condition such as depth and speed of fluid (Table $2-5)$. So once the vessel sail across the Three-Gorge, operation and design of the vessel must take the complicated environment mentioned above into consideration firstly. In the paper the container ship will sail from Changqing to Nanjin (distance: $1887 \mathrm{~km}$ ), through the Three-Gorge.

\begin{tabular}{|c|c|c|c|}
\hline period & low & middle & high \\
\hline days & 90 & 65 & 210 \\
\hline depth & $<2.6$ & $2.6 \sim 3.5$ & $>3.5$ \\
\hline
\end{tabular}

Table 2. speed and depth of parts in three periods (depth: $\mathrm{m}$ )

\begin{tabular}{|c|c|c|c|c|}
\hline period & \multicolumn{4}{|c|}{ low } \\
\hline part & above & reservoir & between & below \\
\hline speed & 0.608 & 0.608 & 1.215 & 3.232 \\
\hline distance & 0 & 490 & 38 & 1359 \\
\hline
\end{tabular}

Table 3. speed and distance of parts in low period (speed of fluid: $\mathrm{km} / \mathrm{h}$, distance: $\mathrm{km}$ )

\begin{tabular}{|c|c|c|c|c|}
\hline period & \multicolumn{4}{|c|}{ middle } \\
\hline part & above & reservoir & between & below \\
\hline speed & 5.12 & 2.097 & 4.193 & 4.405 \\
\hline distance & 0 & 490 & 38 & 1359 \\
\hline
\end{tabular}

Table 4. speed and distance of parts in middle period (speed of fluid: $\mathrm{km} / \mathrm{h}$, distance: $\mathrm{km}$ ) 


\begin{tabular}{|c|c|c|c|c|}
\hline period & \multicolumn{4}{|c|}{ high } \\
\hline part & above & reservoir & between & below \\
\hline speed & 7.64 & 3.736 & 7.471 & 5.836 \\
\hline distance & 195 & 295 & 38 & 1359 \\
\hline
\end{tabular}

note: "above" refers to natural part above dam; "between" refers to between two dams; "below" refers to natural part below dam.

Source: Report of hydrographical condition of the Yangtze River by CCS in 2004

Table 5. speed and distance of parts in high period (speed of fluid: $\mathrm{km} / \mathrm{h}$, distance: $\mathrm{km}$ )

\section{Model of the changeable-draft container ship from Chongqing container terminal}

Due to several general factors such as investment decisions and delayed production as well as case-specific reasons such as varying depth, ranges and not enough container ships available, new container ships should be built which could change the draft according to the varying depth of the fluid, because this kind of vessels could make good use of the water depth to transport the goods as much as possible. The key question is that the days of each period are not fixed because the hydrographical conditions change every year. If the low period lasts for a long time, ship should reduce the TEU every trip and the whole throughput of the terminal will be less. This will affect the traffic volume of the whole year, which will make the freight rate vary in the market and change the investment decision of the ship-owners. In the paper a system dynamics model concerning of the issue of the new building of changeable-draft container ships has been designed which links future container shipment to the new capacity-enlargement decisions.

As a start point in the simulation, the total transportation capacity is based on the data mentioned above (92 thousand TEU at the Chongqing terminal in 2003), when there are 9 container ships whose capacity is 144TEU available (Liu, 2005). Assuming the trade is transporting containers from Chongqing to Nanjing (Fig.1), these 9 ships would have a combined container capacity of 38 thousand TEU per month in general, which can have 30 roundtrip voyages in a month. During the low depth period, the ship should load less TEU, and during the high depth period, it should load more. Since it is a complex issues and subject to many reality operation things, but for modeling purposes it is assumed that varying days of the different period will increase the total transport volume to 82 thousand TEU per month ${ }^{1}$.

The days that low period and high period last for have a great effect on the container ship capacity named total available container ship capacity in Fig.4. When the varying depth is taken into account, the total container ship capacity will be limited, but there still is a limitation of the increase of ship capacity. The maximum of the total container ship capacity will be equal to the design capacity of Chongqing terminal in the future.

1 In the research paper of standard type vessels in the Yangtze River and Three-Gorge Reservoir by Wuhan University of Technology, 2004, if the low period lasts for 3 months at the depth of $2.6 \mathrm{~m}$ and the high period lasts for 7 months at the depth of $3.5 \mathrm{~m}$, the total transportation volume of the whole year is equal to 2.2 times volume of the ship serves at $3 \mathrm{~m}$ depth for 12 months. 
Since the container ship in the market at present can not fulfill the container transportation demand, new ships must be built. As we know, shipbuilding needs a few years before newly constructed capacity is delivered into the market. In the simulation 2 years delay is adopted for although 2 years may be overoptimistic in today's shipbuilding market, but it is adequate for modeling purposes which is mainly to analyze the characteristics of a system in which pattern of increase container ship capacity goes. In the model, the initial capacity of Chongqing terminal is set to 92 thousand TEU per year, which is the terminal's true capacity when it was taken into operation in 2003 (Liu, 2005). From the programming of the Ministry Communications of China, the total capacity of Chongqing container terminal will reach 700 thousand TEU per year in 2010 (Liu, 2005). So the terminal capacity expands in steps of 21 thousand TEU and 40 thousand TEU per year after 5 years and 3 years from the beginning of operations in $2003^{2}$. Then the final capacity of the terminal is 702 thousand TEU per year in the model, which is assumed to last for 5 years.

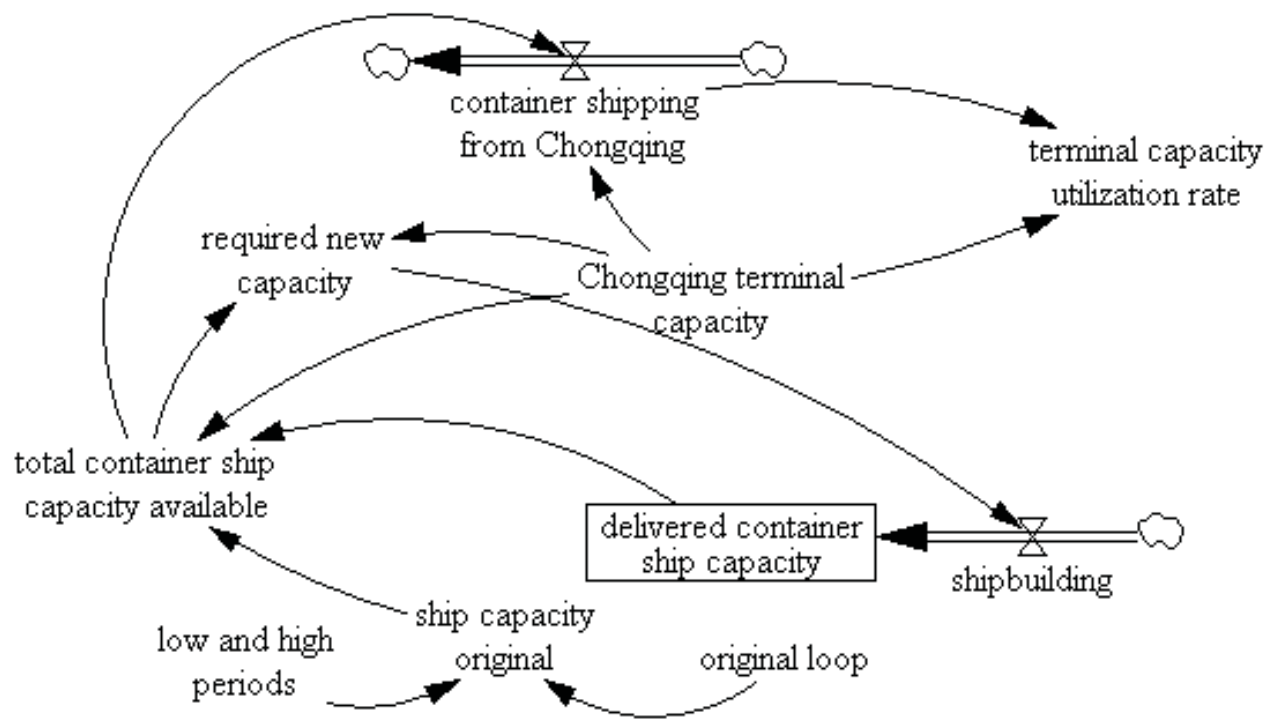

Fig. 4. System dynamics model for the container shipment of the Chongqing terminal

The equations used in the simulation model as follows:

(01) Delivered container ship capacity = INTEG(shipbuilding,0)

Units: Ten thousand TEU per year

(02) Final Time $=50$

Units: Year

(03) Ship capacity original = Original loop (low and high periods)

Units: Dmnl

(04) Initial Time $=0$

Units: Year

2 Website of the Ministry Communications of China: http:/ /www.moc.gov.cn/ 
(05) Container shipping from Chongqing = IF THEN ELSE(Chongqing terminal capacity>total container ship capacity available, total container ship capacity available, Chongqing terminal capacity)

Units: Ten thousand TEU per year

(06) Chongqing terminal capacity $=9.2+\operatorname{step}(21,5)+\operatorname{step}(40,2)$

Units: Ten thousand TEU per year

(07) Required new capacity $=$ Chongqing terminal capacity-total container ship capacity available

Units: Ten thousand TEU per year

(08) Shipbuilding = DELAY FIXED(required new capacity, 2, 0 )

Units: Ten thousand TEU per year

(09) Terminal capacity utilization rate = container shipping from Chongqing/Chongqing terminal capacity

Units: percent

(10) SAVEPER = TIME STEP

Units: Year [0,?]

The frequency with which output is stored

(11) TIME STEP $=1$

Units: Year [0,?]

The time step for the simulation

(12) Total available container ship capacity = IF THEN ELSE (ship capacity original $^{*} 8.2 / 9^{*} 12+$ delivered container ship capacity $>$ Chongqing terminal capacity, Chongqing terminal capacity, ship capacity original ${ }^{*} 8.2 / 9 * 12+$ delivered container ship capacity)

Units: Ten thousand TEU per year

(13) Low and high periods $=1,3,5,7,11$

Units: month

The model assumes that the total volume of containers to be shipped from the Chongqing terminal cannot exceed the capacity of the terminal and the terminal capacity utilization rate is the ratio of the actual volume of container shipping from Chongqing terminal and the existing export capacity of the terminal, which can show the effect of the terminal actual operation and whether the existing capacity is suitable for the demand expansion.

\section{Result analyses}

The simulation runs under the five kinds of distribution in the days of the low period and high period condition. That is the low period will last for 1 month, 3 months, 5 months, 7 months and 11 months, and the high period will last for 11 months, 7 months, 5 months, 3 months and 1 month corresponding, for the total of the low and high period should be 10 months and the middle period lasts for 2 months in general. In the simulation the whole time is set to 50 years in order to make the patterns' tendency more visible using 25 years on the $x$-axis and the results are in Fig.5-7.

From Fig.5, it is obvious that the container ship capacity needed exactly follows the increase of the Chongqing terminal capacity, no matter what the distribution of the low and high period is. The supply of the container ship capacity should increase infinitely theoretically for all suitable-sized vessels in China may be used in the container trade, but the model is 
designed from the terminal points of view, so there is the limitation which the maximum of the ship capacity expansion is the final design capacity of the terminal in the model. Nearly in all the scenarios it takes about seven years before the capacity of vessels reaches the terminal's final capacity under the developing speed of the construction of the terminal. In all the scenarios except 1 month low, the new building delay forces the capacity to overshoot the goal level before corrective measures are taken in Fig.4. At this time the freight rate surely is at the peak and will go downward later. The high level of deliveries of the ship also is the trigger for increased deliveries and the ship-owner should consider carefully when he wants to invest at this moment.

The relationship between different ratio of the low and high periods and the deficits in available vessel capacity ultimately gives the push of ship building. In the case of 1 month low, the depth maintain the high level nearly the whole year, the existing vessels could hold as more containers as possible, so the new building demand of the container ships is lower than other scenarios. Oppositely, the incentive for new building construction is the high freight rates caused by capacity deficits because of the insufficient supply of the container ships.

The number of container ships to be constructed can be obtained from the simulated new container ship building pattern in Fig.6. With the real capacity of 82 thousand TEU 9 ships per month, a simulated new-built capacity of 47 ten thousand TEU per year can be translated to nearly 5 new 144 TEU container ships $(47 /(8.2 * 12 / 9))$, which could fully cover the transport demand although in the long low depth period.

\section{total container ship capacity available}

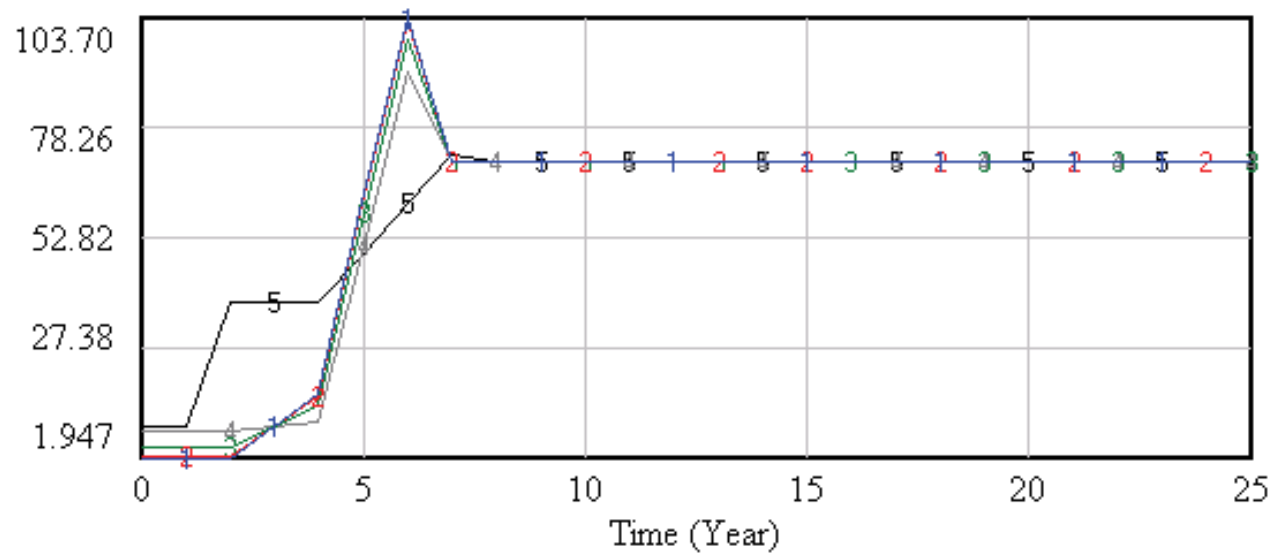

total container ship capacity available : 11 monthlow total container ship capacity available : 7 monthlow total container ship capacity available : Smonthlow total container ship capacity available : 3 monthlow total container ship capacity available : 1 monthlow

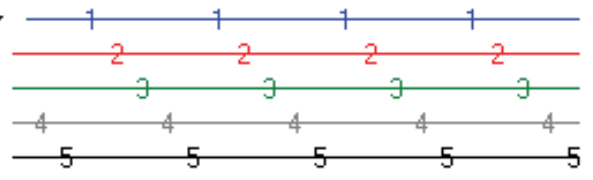

Fig. 5. Container ship capacity per year in different simulation scenarios 


\section{shipbuilding}

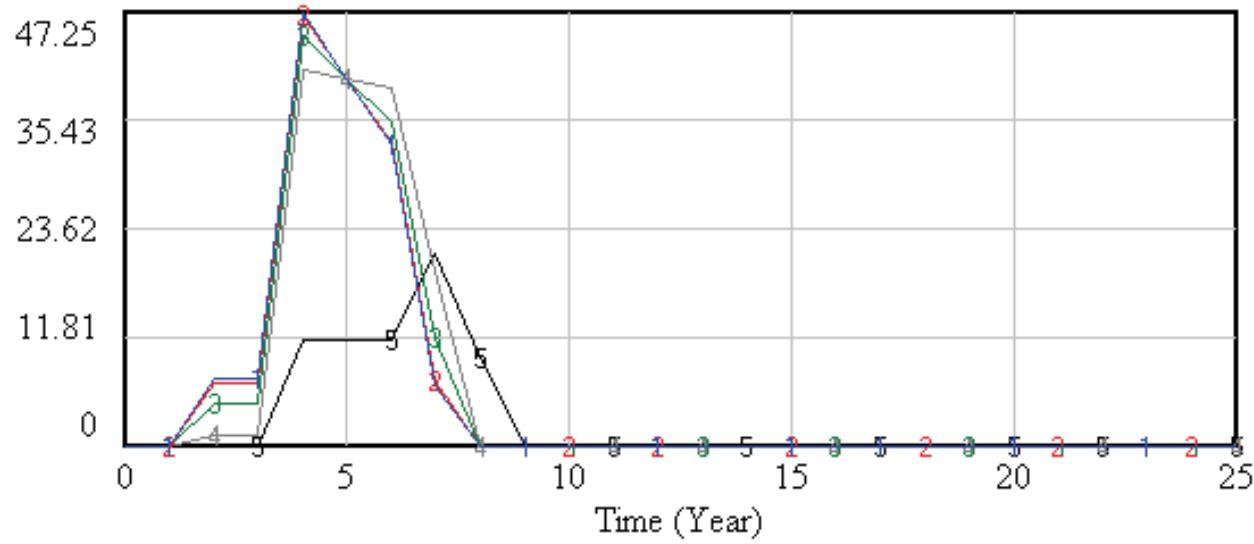

shipbuilding : 11 monthlow shipbuilding : 7monthlow shipbuilding : Smonthlow shipbuilding : 3monthlow shipbuilding : 1 monthlow

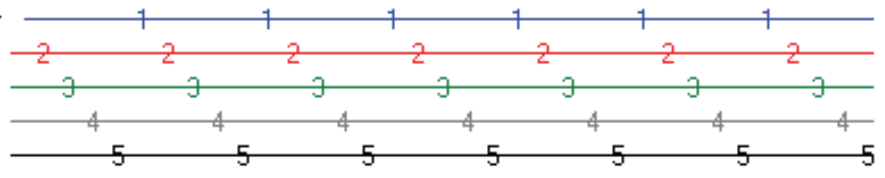

Fig. 6. New container ship building pattern in different simulation scenarios

terminal capacity utilization rate

0.75

1

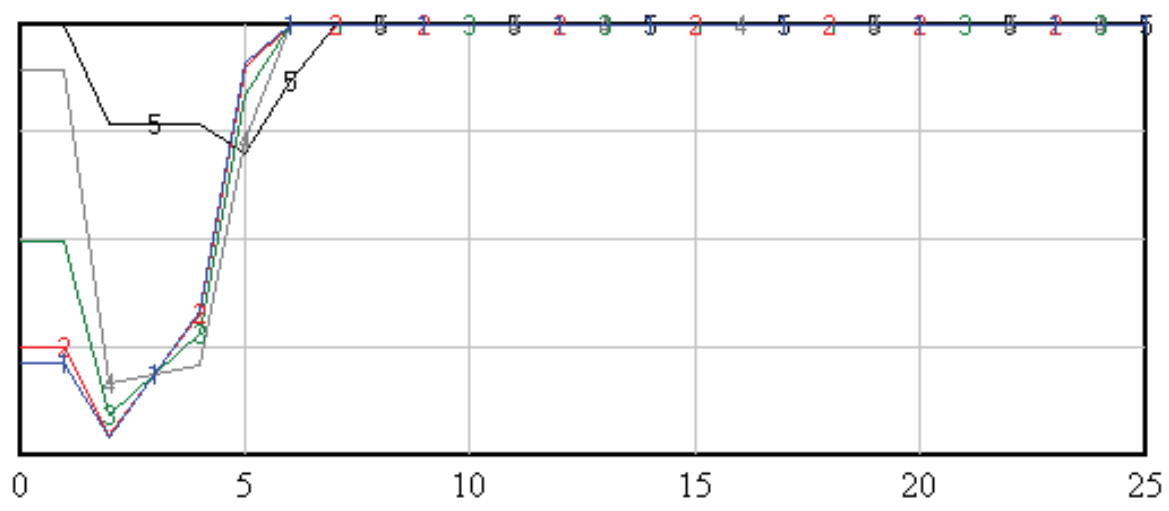

Time (Year)

terminal capacity utilization rate : 11 monthlow terminal capacity utilization rate : 7 monthlow terminal capacity utilization rate : Smonthlow terminal capacity utilization rate : 3monthlow terminal capacity utilization rate : 1 monthlow

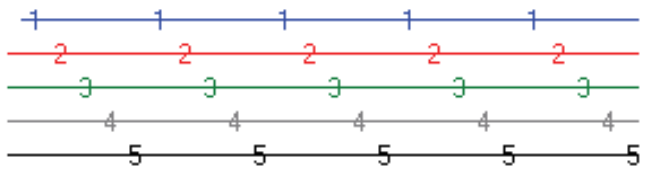

Fig. 7. Chongqing terminal utilization rate in different simulation scenarios 
The way by which different ratio of the low and high period and the ship building delay affect the container transported from the Chongqing terminal is also showed in Fig. 7. At the beginning of the simulation, the terminal's utilization rate is not limited by ship capacity. But with the time goes on, the ship capacity could not satisfy the quick increase of the containers and the utilization rate of terminal capacity falls to a very low level, even to $10 \%$ in 11 month low scenario. Then the construction of new ships makes up the low level of terminal capacity utilization nearly after 7 or 8 years.

In the simulation, since a key factor is the delay time of the new ship building, a sensitivity analysis was done by changing the time from 2 years to 1, 3 and 5 years. From the result of the analysis, the patters of the behavior in container ship capacity, new ship building and terminal utilization rate in different scenarios were nearly the same as the figures given above. The only difference is that it takes either a litter shorter or longer time before the ship capacity reaches the desired level. During the all analysis, the most important factor is the ratio of the low and high periods distribute.

\section{Conclusions}

The system dynamics simulation gives the developing patterns of the container ship capacity and the terminal capacity under different hydrographical conditions of the Yangtze. The result of the simulation shows that the ship capacity expansion is incentive by the deficit supply and the occasional water depth. If new ship building is only encouraged by them, the container ship fleet growth will be slow, which will induce the low terminal utilization rate for a long time. The Three-Gorge Dam Project will be finished completely in 2008. At that time, the fluid condition of the upstream in the Yangtze will change which will be more suitable for the large draft vessels. On the other side, from the simulation, it is obvious that the new ship building delay will make the oversupply for some time in the market. So there are some investment risks. In order to guarantee adequate ship capacity from the beginning of the terminal operations, new container ships order should be made well in advance.

From the change of the river hydrographical condition, changeable-draft container ships are needed. From the development of the Chongqing terminal, new ship capacity is needed for the capacity deficit in the market. But in practice, the long-term chartering agreements between shippers and ship-owners without some certainty on freight rates will put some risks on the investment of the new ship building. The rough simulation in the paper gives the general patterns of some behavioral factors. There are some other works needed to research further on this base, such as the containers demand decided by the business should be considered for the pattern of demand's behavior in the market surges usually if the research time is long. But in this paper there is the background of the booming demand of the container transportation in the Yangtze, the tendency of the demand is going up, so it is reasonable to use the expansion of the terminal's capacity in the rough model. Also the investment decision of the government to the terminal and ship building industry and the pollution of the ship industry to the river are the factor affected the ship growing because all of them are included in the big system. If we want the whole system to be working in a good circle behavior, the elements taken into consideration should be as much as possible. 


\section{Acknowledgements}

This paper is part of research financed by the European Commission Asia-link Program (Project no. VN010). Partners in this project are CICAT-Delft University of Technology, Wuhan University of Technology, Vietnam Maritime University and University of AntwerpDepartment of Transport and Regional Economics.

\section{References}

Beenstock, M., A. Vergottis., Econometric Modeling of World Shipping (International Studies in Economic Modeling), Chapman and Hall, London, UK, 1993.

Charemza, W. and Gronicki, M., An econometric model of world shipping and shipbuilding. Maritime Policy \& Mannagement, 1981, 10(1), pp.21-30.

Coyle, RG, Management System Dynamics, John Wiley \& Sons Ltd: London, 1977.

Devanney, J., F. Fischer, Marine Decisions Under Uncertainty, MIT Lecture Series, MIT Press, Cambridge, MA,1971.

Dikos,G. and Papadatos, P. M. The case of tanker freight rate dynamics, Proceedings of the IAME 2005 Congress, Cyprus.

Dikos,G., Marcus, H. S., Papadatos, P. M. and Papakonstantinou, V., Niver Lines: A System-Dynamics Approach to Tanker Freight Modeling, Interfaces, 2006,36(4), pp.326-341.

Eriksen, I. E. and Norman, V. D., Econometric model for tanker companies. Institute of Shipping Reaearch, Norwegian School of Economics and Business Adiminstration, Bergen,1976.

Jay W. Forrester, Policies, decisions and information sources for modeling, European Journal of Operational Research, 1992(59), pp.42-63.

Jostein Tvedt, Shipping market models and the specification of freight rate processes, Maritime Economics \& Logistics,2003(5),pp.327-346.

Khaled A. A., Michael G. H. B., System Dynamics Applicability to Transportation Modelling, Transpn. Res.-A, 1994 (28)(5),pp.373-400.

Koopmans, T. C., Tanker Freight Rates and Tankship Building, 1939

Richardon, G.P., Feedback Thought in Social Science and Systems Theory, University of Pennsylvania Press, Philadelphia, PA,1991.

Serghiou, SS, Serghios, S and Zannetos, ZS. The level and structure of single voyage freight rates in the short run, Transportation Science, 1982(16), pp.19-44.

Strandenes, S.P. Economics of the Markets for Ships in C. Th. Grammenos editor. The handbook of Maritime Economics and Business. 2002

Sterman, J. D., Business Dynamics. Systems Thinking and Modeling for a Complex World, McGraw-Hill, New York, 2000.

Stopford, M., Maritime Economics. Routledge, London, UK, 2002.

Tinbergen, J., Scheepsbouwruimet en vrachten. De Nederlandse Conjunctuur, 1934 March, pp.23-35

Veenstra, AW and Ludema, MW, Cyclicality in the oil tanker shipping industry. Conference Paper Presented in September 2003, Riga, Latvia, Rotterdam School of 
Economics/Centre for Maritime Economics and Logistics: The Netherlands, 2003.

Zannetos, ZS. The Theory of Oil Tankship Rates. The MIT Press: MA USA, 1966.

Zhuyuan Liu, The development analysis of the main container terminals in China in 2010, Water Transportation Digest, 2005(2), pp.8-13. (in Chinese). 


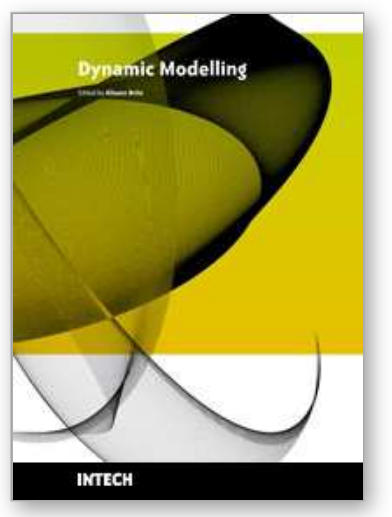

\author{
Dynamic Modelling \\ Edited by Alisson V. Brito
}

ISBN 978-953-7619-68-8

Hard cover, 290 pages

Publisher InTech

Published online 01, January, 2010

Published in print edition January, 2010

When talking about modelling it is natural to talk about simulation. Simulation is the imitation of the operation of a real-world process or systems over time. The objective is to generate a history of the model and the observation of that history helps us understand how the real-world system works, not necessarily involving the real-world into this process. A system (or process) model takes the form of a set of assumptions concerning its operation. In a model mathematical and logical assumptions are considered, and entities and their relationship are delimited. The objective of a model - and its respective simulation - is to answer a vast number of "what-if" questions. Some questions answered in this book are: What if the power distribution system does not work as expected? What if the produced ships were not able to transport all the demanded containers through the Yangtze River in China? And, what if an installed wind farm does not produce the expected amount of energyt? Answering these questions without a dynamic simulation model could be extremely expensive or even impossible in some cases and this book aims to present possible solutions to these problems.

\title{
How to reference
}

In order to correctly reference this scholarly work, feel free to copy and paste the following:

Yan Jin (2010). Investment in Container Ships for the Yangtze River: A System Dynamics Model, Dynamic Modelling, Alisson V. Brito (Ed.), ISBN: 978-953-7619-68-8, InTech, Available from:

http://www.intechopen.com/books/dynamic-modelling/investment-in-container-ships-for-the-yangtze-river-asystem-dynamics-model

\section{INTECH}

open science | open minds

\section{InTech Europe}

University Campus STeP Ri

Slavka Krautzeka 83/A

51000 Rijeka, Croatia

Phone: +385 (51) 770447

Fax: +385 (51) 686166

www.intechopen.com

\section{InTech China}

Unit 405, Office Block, Hotel Equatorial Shanghai

No.65, Yan An Road (West), Shanghai, 200040, China

中国上海市延安西路65号上海国际贵都大饭店办公楼405单元

Phone: +86-21-62489820

Fax: +86-21-62489821 
(C) 2010 The Author(s). Licensee IntechOpen. This chapter is distributed under the terms of the Creative Commons Attribution-NonCommercialShareAlike-3.0 License, which permits use, distribution and reproduction for non-commercial purposes, provided the original is properly cited and derivative works building on this content are distributed under the same license. 